\title{
Hand and Mechanical Fruit-zone Leaf Removal at Prebloom and Fruit-set Was More Effective in Reducing Crop Yield than Reducing Bunch Rot in 'Riesling' Grapevines
}

\author{
Bryan Hed ${ }^{1}$ and Michela Centinari ${ }^{2,3}$
}

\begin{abstract}
AdDitional Index wORDs. Botrytis cinerea, canopy microclimate, cluster compactness, cultural practice, mechanization, Vitis vinifera

SUMMARY. Fruit-zone leaf removal is typically applied in cool and humid regions to improve grape and wine quality, while reducing disease pressure. When fruit-zone leaf removal is applied early in the season, before bloom [early leaf removal (ELR)], it also reduces fruit-set, cluster compactness, and susceptibility to bunch rot, a complex disease that involves fungi (Botrytis cinerea, Aspergillus sp., Penicillium sp.) and bacteria (Acetobacter sp.). Over 2 years (2015-16), we tested whether ELR applied mechanically [mechanical defoliation at stage E-L 18 (MD-I)] would mimic the effects of a hand removal [hand defoliation of the first six basal leaves and laterals at stage E-L 18 (Coombe, 1995) (HD-I)] with respect to 'Riesling' (Vitis vinifera) production parameters, canopy density and cluster sunlight exposure, fruit composition, and bunch rot control. We also compared the effects of mechanical defoliation applied either at prebloom (MD-I) or at fruit-set [mechanical defoliation at stage E-L 27 (MD-II)]. In both years, fruit-zone leaf removal, regardless of method and timing, reduced yield, cluster weight, and berries per cluster, while maintaining fruit composition and bud fruitfulness as compared with nondefoliated vines (control, C). In 2015, HD-I vines had a lower percentage of clusters infected by bunch rot as compared with the $\mathrm{C}$ and MD-II vines. However, severity of bunch rot was low in all treatments, and there was not significant treatment effect on bunch rot severity in either year. ELR consistently shortened cluster length, offsetting much of the intended cluster loosening effect induced by a lower number of berries per cluster-that would have reduced bunch susceptibility to late seasons rots. Despite removing only half the leaf area of HD-I, MD-I successfully mimicked the canopy improving effects of HD-I in terms of fewer interior clusters and leaves, fewer cluster-shading layers, and greater light available to clusters and leaves as compared with $\mathrm{C}$ vines.
\end{abstract}

' $\mathrm{R}$ iesling' is a white wine grape cultivar widely grown in the northeastern United States because of its suitability for the regional climatic conditions, including its relative cold hardiness and ability to produce high-quality wines

This work was supported by the Pennsylvania Wine Marketing and Research Board and by the USDA National Institute of Food and Agriculture Federal Appropriations under Project PENO 4572 and Accession number 1003709

We thank Sarah and Galen Troxell at Galen Glen Winery for providing and maintaining the vineyard experimental site and implementing the mechanical defoliation; Andrew Harner, Suzanne Fleishmann, William Schultz, and Abel Engler for field and laboratory assistance; and Rich Marini and Rob Crassweller for comments on the manuscript.

${ }^{1}$ Department of Plant Pathology and Environmental Microbiology, Lake Erie Regional Grape Research and Extension Center, The Pennsylvania State University, North East, PA 16428

${ }^{2}$ Department of Plant Science, The Pennsylvania State University, Tyson Building, University Park, PA 16802

${ }^{3}$ Corresponding author. E-mail: mzc22@psu.edu.

https://doi.org/10.21273/HORTTECH03965-18
(Reisch et al., 1993). However, a major challenge associated with growing 'Riesling', especially in humid climates, is its susceptibility to bunch rot infections (Barbetti, 1980). Bunch rot-associated fungi and bacteria invade the soft, sweet, and senescing fruit during the ripening period, compromising grape composition and wine quality (Steel et al., 2013). The compactness of grape clusters favors the colonization and spread of bunch rot organisms within the cluster (Zitter and Wilcox, 2004). Therefore, wine grape cultivars with compact clusters, such as Riesling, are more susceptible to bunch rot than those with loose clusters (Vail and Marois, 1991; Vail et al., 1998).

Fruit-zone leaf removal, traditionally applied between fruit-set and veraison, is commonly used in cool climate grape-growing regions to improve fruit-zone microclimate and spray coverage and to decrease disease pressure (Austin et al., 2011; English et al., 1989; Komm and Moyer, 2015). When fruit-zone leaf removal is applied earlier, prebloom or beginning of bloom (ELR), a greater amount of leaf area is removed on a per-shoot basis (Risco et al., 2014). Basal leaves are the primary source of assimilates at bloom and the major determinant of fruit-set (Caspari et al., 1998; Poni et al., 2006). Consequently, removing basal leaves prebloom can reduce fruit-set and the number of berries per cluster, leading to smaller and less compact clusters (Diago et al., 2010; Poni et al., 2006; Sabbatini and Howell, 2010). Therefore, ELR could be an effective tool for reducing bunch rot infections, as it combines a reduction in cluster compactness with an improvement of canopy microclimate and spray coverage (Diago et al., 2010; Sabbatini and Howell, 2010; Tardaguila et al., 2010).

ELR has also been used to favorably reduce crop level in high-yielding wine grape cultivars such as Sangiovese, Barbera, and Tempranillo, especially in regions where crop levels are legally restricted (Intrieri et al., 2008; Poni et al., 2006; Tardaguila et al., 2010). Additional benefits related to

\begin{tabular}{llll}
\hline $\begin{array}{l}\text { Units } \\
\begin{array}{l}\text { To convert U.S. to SI, } \\
\text { multiply by }\end{array}\end{array}$ & U.S. unit & SI unit & $\begin{array}{l}\text { To convert SI to } \\
\text { U.S., multiply by }\end{array}$ \\
\hline 10 & $\%$ & $\mathrm{~g} \cdot \mathrm{L}^{-1}$ & 0.1 \\
29.5735 & $\mathrm{fl} \mathrm{oz}$ & $\mathrm{mL}$ & 0.0338 \\
0.3048 & $\mathrm{ft}$ & $\mathrm{m}$ & 3.2808 \\
0.0929 & $\mathrm{ft}^{2}$ & $\mathrm{~m}^{2}$ & 10.7639 \\
0.2048 & $\mathrm{ft}^{2} / \mathrm{lb}$ & $\mathrm{m}^{2} \cdot \mathrm{kg}^{-1}$ & 4.8824 \\
2.54 & inch $(\mathrm{es})$ & $\mathrm{cm}$ & 0.3937 \\
25.4 & inch $(\mathrm{es})$ & $\mathrm{mm}$ & 0.0394 \\
6.4516 & inch & $\mathrm{cm}$ & 0.1550 \\
0.4536 & $\mathrm{lb}$ & $\mathrm{kg}$ & 2.2046 \\
1.6093 & $\mathrm{mph}$ & $\mathrm{km} \cdot \mathrm{h}^{-1}$ & 0.6214 \\
28.3495 & $\mathrm{OZ}$ & $\mathrm{g}$ & 0.0353 \\
$\left({ }^{\circ} \mathrm{F}-32\right) \div 1.8$ & ${ }^{\circ} \mathrm{F}$ & ${ }^{\circ} \mathrm{C}$ & $\left({ }^{\circ} \mathrm{C} \times 1.8\right)+32$
\end{tabular}


improved fruit-zone microclimate of ELR vines include an enhancement of fruit composition at harvest. ELR increased total soluble solids (TSS), anthocyanin, and phenol content in several red wine grape cultivars (Diago et al., 2012b; Poni et al., 2009; Risco et al., 2014) and positively influenced wine phenolic composition in Tempranillo ( $V$. vinifera) (Diago et al., 2012a) and grape aroma and wine sensory profile in Semillon ( $V$. vinifera) (Alessandrini et al., 2017). Yet, the effects of ELR are not consistent and improvements in fruit and wine composition were not always observed (Diago et al., 2010; Sabbatini and Howell, 2010; Tardaguila et al., 2010).

Although ELR is an innovative viticulture practice gaining popularity around the world from Mediterranean to cool and humid grape-growing regions, shortages and increasing costs of labor may limit its adoption. To overcome this problem, growers in some grape-growing regions, such as Oregon, have shifted to mechanical defoliation (Skinkis, 2013). Mechanization could potentially reduce management costs. However, there is concern regarding less precision and potential damage to the clusters using mechanical rather than hand defoliation (Skinkis, 2013). The feasibility of mechanical ELR was tested mainly in Europe (Diago et al., 2010; Intrieri et al., 2008; Tardaguila et al., 2010), leading, in some situations, to reductions in crop level and improvement in fruit composition comparable to hand defoliation (Diago et al., 2012b; Tardaguila et al., 2010).

The objective of this study was to optimize the use of leaf removal for crop and disease management of 'Riesling' grapevines under humid and cool climate conditions. We evaluated and compared the effects of ELR method (hand and mechanical) and leaf removal timing (mechanical ELR and mechanical leaf removal at fruit-set) on canopy microclimate and density, yield components, cluster morphology, bunch rot development, and fruit composition in a commercial 'Riesling' vineyard in a cool, wet region of Pennsylvania. Mechanical defoliation at fruit-set-the standard practice for the grower cooperatorwas included to investigate whether earlier, prebloom leaf removal would further reduce crop losses to bunch rot, while maintaining or improving grape production and quality parameters.

\section{Materials and methods}

The experiment was conducted in 2015 and 2016 in a commercial, nonirrigated vineyard of 'Riesling' (clone 198) grafted onto 101-14 Mgt rootstock (Vitis riparia $\times$ Vitis rupestris) and planted in 2010. The vineyard was located near Andreas, PA (lat. $40^{\circ} 75^{\prime} \mathrm{N}$, long. $75^{\circ} 79^{\prime} \mathrm{W}$ ), in the Lehigh Valley American Viticultural Area. The soil was classified as Berks, shaley loam (U.S. Department of Agriculture, 2017). Vine spacing was $5 \mathrm{ft}$ between vines and $8 \mathrm{ft}$ between rows, with an orientation of $35^{\circ}$ north-northwest. The vines were cane pruned and trained to a bilateral vertical shoot-positioned trellis system. The canes were horizontally tied to a basal wire located 36 inches from the ground. Three sets of catch wires were positioned 8,20 , and 36 inches above the basal wire. The vines were thinned to an average of 10-12 shoots $/ \mathrm{m}$. Shoots were hedged twice during the season, mid-July, and early mid-August. Standard disease and insect control practices for wine grape cultivars in the eastern United States were applied (Wolf, 2008).

The experiment was setup as a randomized complete block design with four blocks. Each experimental unit consisted of two sections of two post spaces $(8-10$ contiguous vines; 40-50 ft long row). Treatments consisted of 1) nondefoliated C, 2) early hand defoliation (HD-I) of the first six basal main leaves and laterals of each shoot at stage E-L 18 (Coombe, 1995), 3) early mechanical defoliation (MD-I) at stage E-L 18, and 4) mechanical defoliation (MD-II) at fruit-set (E-L 27).

Before HD-I and MD-I, eight uniform shoots bearing two inflorescences were selected and flagged from each experimental unit and used for leaf area and cluster measurements. Treatments HD-I and MD-I were concurrently applied on 4 June 2015 and 7 June 2016. MD-II was applied on 17 June 2015 and 21 June 2016. Mechanical defoliation was performed with a tractor-mounted, pulsed-air leaf remover (Collard, Bouzy, France). The machine operates by blowing compressed air into the fruit-zone with enough pressure to shatter leaf tissue, while leaving inflorescences relatively unscathed (Tardaguila et al., 2010). The tractor speed was $1.4 \mathrm{mph}$ and the head speed was set at $850 \mathrm{rpm}$. MD was applied to both sides of the canopy, one pass on each side. To mimic the hand defoliation, the air shear system head was positioned close to the canopy at fruit-zone height to remove leaves at basal nodes one to six.

ELR was also performed on 8 June 2017, but leaves and clusters were heavily damaged by the drift of growth regulator herbicide from a nearby field shortly after treatment implementation. Therefore, we were not able to collect a third season of data. The only data collected in 2017 and presented in the article are the visual assessment of inflorescence damage caused by MD-I.

EVALUATION OF PHYSICAL DAMAGE TO INFLORESCENCES BY MD. In 2017, each inflorescence of the flagged shoots in the MD-I treatment was photographed against a white background. Photos were taken immediately before and after MD-I with a digital camera (Camedia; Olympus, Tokyo, Japan) held perpendicular to the inflorescence. The number of flowers visible in each photo taken before and after MD-I was counted using Microsoft Office Paint (Windows 7 Enterprise; Microsoft, Redmond, WA) (Acimovic et al., 2016). The number of inflorescences damaged and the percentage of flowers removed by MD-I on each cluster were calculated. It was not possible to repeat the visual assessment of cluster damage after MD-II, as the vines sustained herbicide drift damage.

WeATHER DATA. Weather (air temperature, rainfall, and wind speed) data were recorded by an onsite weather station (Vantage Pro; Davis Instruments, Hayward, CA) and downloaded every $30 \mathrm{~min}$. Growing degree days [GDD (base $10^{\circ} \mathrm{C}$ )] were calculated as GDD $=[($ maximum daily temperature + minimum daily temperature)/2] - 10 .

LeAF AREA MEASUREMENTS. The amount of leaf area removed with ELR was measured in 2015 and 2016 on the same day as the treatments were applied. In the HD-I treatment, main and lateral leaves at nodes one to six were collected from each flagged shoot and their area measured. In the MD-I treatment, any leaves (intact and partially shattered) 
still present at nodes one to six after mechanical defoliation were collected from eight randomly selected shoots for each experimental unit and their area measured. Flagged shoots were avoided for this assessment, so as not to affect subsequent cluster measurements taken on those shoots. Leaf areas were measured with a leaf area meter (LI-3100; LICOR Bioscience, Lincoln, NE). Leaf area removed in the MD-I was estimated by subtracting the leaf area remaining at nodes one to six in the MD-I shoots from the total leaf area removed at the same nodes in HD-I. At harvest, for each flagged shoot, main and lateral leaves were separately removed to determine final main, lateral, and total leaf area per shoot.

The number of leaves still present on the shoot after HD-I (201516) and MD-I (2016) was counted for each flagged shoot. In MD-I, the leaves remaining on the shoots were recorded as either intact or damaged. Because of travel distance to the experimental site and lack of personnel, leaf area removed with MD-II was not measured.

ENHANCED POINT QUADRAT ANALYSIS (EPQA). Enhanced point quadrat analysis (Meyers and Vanden Heuvel, 2008) was performed on 13 Aug. 2015 and 20 Aug. 2016, shortly after veraison. Point quadrat analysis was used to characterize canopy structure: a thin metal rod was inserted horizontally through the fruit-zone perpendicular to the vine row at $20-\mathrm{cm}$ intervals for a total of 36 insertions per experimental unit. Photosynthetically active radiation $(P A R)$ was measured with a ceptometer (AccuPAR LP-80; Meter Group, Pullman, WA) within $2 \mathrm{~h}$ of solar noon on the same day under clear, sunny conditions. The in-canopy photon flux values were calculated as the ratio of the within-canopy and ambient $P A R$. For each experimental unit, the ceptometer was positioned in the canopy interior parallel to the row and at the fruit-zone height with the sensors facing upward. Five photon flux measurements were taken for each experimental unit, whereas one ambient PAR measurement was taken by holding the ceptometer in the row middle, above the canopy. Canopy structure and photon in-canopy flux data were analyzed using Canopy Exposure Mapping Tools, version 1.7 (available free of charge from J.M. Meyers, Cornell University, Ithaca, NY). This software was developed to calculate occlusion layer number, leaf and cluster exposure flux availability, and cluster exposure layers (Meyers and Vanden Heuvel, 2008).

Yield Parameters, Cluster MORPHOLOGY, BUNCH ROT, AND FRUIT COMPOSITION. At harvest (26 Sept. 2015 and 27 Sept. 2016), the incidence (percentage of clusters infected) and severity (percentage of the cluster's area infected) of bunch rot were determined on basal and distal clusters on 16 shoots in 2015 and 20 shoots in 2016 from six central vines of each experimental unit. Severity was rated using the Barratt-Horsfall scale (Horsfall and Barratt, 1945) and converted to percentage of area infected using Elanco conversion tables (Redman et al., 1969).

After bunch rot rating, the basal and distal clusters of each flagged shoot were individually harvested, weighed, and stored at $-20^{\circ} \mathrm{C}$ until analysis. Then, the clusters of each experimental unit were counted and weighed with a scale (CCI Scale Co., Ventura, CA) accurate to $0.1 \mathrm{~kg}$, and average yield and cluster number per vine were calculated.

For each cluster of the flagged shoots, the number of berries was counted and the length of the main rachis was measured from the first lateral (below the cluster shoulder or wing, if there was one) down to the bottom of the rachis (Hed et al., 2015). Cluster compactness was determined as the number of berries on the main rachis divided by the length of the main rachis and expressed as berries per centimeter. The number of pieces of dehiscent floral debris retained in each cluster was also counted (Hed et al., 2009).

A subsample of frozen berries from each experimental unit $(\approx 500 \mathrm{~g})$ was thawed in a water bath at $60{ }^{\circ} \mathrm{C}$, then ground in a blender (Osterizer; Sunbeam Products, Boca Raton, FL), and strained through cheesecloth to remove solids. Total soluble solids was measured using a refractometer (Abbe Mark II; Reichert, Depew, NY) and $\mathrm{pH}$ was determined using a $\mathrm{pH}$ meter (Symphony B I0P; VWR International, Radnor, PA). Titratable acidity (TA) was measured with a manual titrator
(Titronic Universal Titrator; SI Analytics, Mainz, Germany), where a $10-\mathrm{mL}$ juice sample was diluted with $40 \mathrm{~mL}$ of distilled water and titrated with $0.10 \mathrm{~N}$ sodium hydroxide $(\mathrm{NaOH})$ to an end point $\mathrm{pH}$ of 8.20. Year-after effects on bud fruitfulness was determined by counting the number of inflorescences developed on 16 randomly selected shoots per experimental unit on 7 June 2016 and 8 June 2017.

Data ANALYsis. Statistical analysis was carried out using the SAS software package (version 9.4; SAS Institute, Cary, NC). Data were subjected to analysis of variance using MIXED procedure. Year was considered a fixed variable and included in the model for all data collected in both seasons. Block was included as a random effect. Differences between treatment means were assessed by Tukey's honestly significant difference pairwise comparison test.

\section{Results}

Weather Data. Overall, GDD and rainfall accumulated from 1 Apr. to 30 Sept. were similar between years (Fig. 1). Total GDD accumulation was only 30 GDD higher in 2015 as compared with 2016 (1687 vs. 1657 GDD), whereas total rainfall was only $21 \mathrm{~mm}$ greater in 2015 than 2016 (620 vs. $599 \mathrm{~mm}$ ). Spring was wetter and warmer in 2015 as compared with 2016 , whereas summer and early fall were dryer and cooler in 2015 than 2016.

LEAF AREA REMOVED, FINAL LEAF AREA AT HARVEST, AND EPQA PARAMETERS. Leaf area mechanically removed with MD-I was on average $50.7 \%$ of that removed by hand (HD-I) (Table 1). The average number of leaves left on the shoot after HD-I was seven in 2015 and eight in 2016. After MD-I, there was an average of five intact and eight damaged leaves left per shoot. At harvest, total leaf area was higher for $\mathrm{C}$ as compared with HD-I and MD-II (Table 1). C vines had the highest main leaf area, but there were no differences in lateral leaf area among treatments.

Regardless of the timing or the method used, defoliated vines had less dense canopies (number of leaf and occlusion layers), fewer interior clusters and leaves, fewer cluster-shading layers (cluster exposure layers), and greater light available to clusters and 

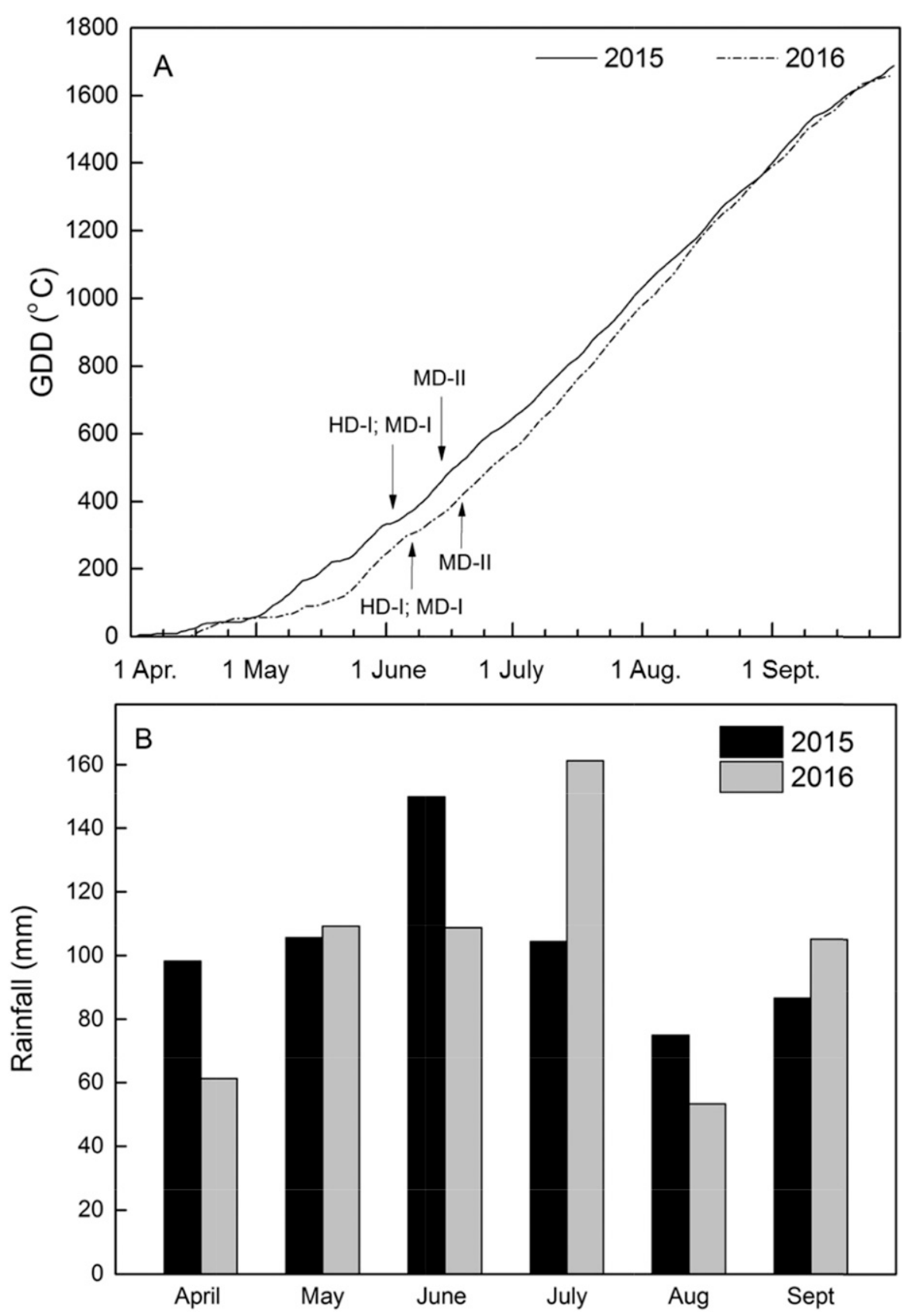

Fig. 1. (A) Cumulative growing degree days [GDD (base $\left.10^{\circ} \mathrm{C}\right)$ ] and (B) average monthly rainfall from 1 Apr. to 30 Sept. 2015 and 2016 at the 'Riesling' vineyard. Arrows indicate the dates of early leaf removal (4 June 2015 and 7 June 2016) and fruit-set leaf removal (17 June 2015 and 21 June 2016). HD-I = hand defoliation of the first six basal leaves and laterals at stage E-L 18 (Coombe, 1995); MD-I = mechanical defoliation at stage E-L 18; MD-II = mechanical defoliation at stage E-L $27 ;\left(1.8 \times{ }^{\circ} \mathrm{C}\right)+32={ }^{\circ} \mathrm{F}, 1 \mathrm{~mm}=0.0394$ inch.

leaves (cluster and leaf exposure flux availability) as compared with $\mathrm{C}$ vines (Table 2).

DAMAGE ON THE INFLORESCENCE. Of the 32 inflorescences analyzed, 12 $(37.5 \%)$ were damaged by MD-I. Damage on the inflorescence ranged from missing a few individual flowers to missing small sections of the rachis. The percentage of damaged flowers per inflorescence, expressed as the ratio between number of flowers before and after MD-I, averaged to $9 \%$.

Yield PARAMETERs, Cluster MORPHOLOGY, BUNCH ROT, AND FRUIT COMPOSITION. In both years, yield and cluster weight of defoliated vines were lower than those of $\mathrm{C}$, regardless of the timing and method of leaf removal. In 2015, average yield per vine ranged from $3.90 \mathrm{~kg}(\mathrm{HD}-\mathrm{I})$ to $4.96 \mathrm{~kg}(\mathrm{C})(P=0.003)$, whereas in 2016 it varied from $3.27 \mathrm{~kg}$ (MD-I) to $4.86 \mathrm{~kg}(\mathrm{C})(P=0.001)$. Compared with $\mathrm{C}, \mathrm{HD}$-I yield per shoot was reduced by $35.0 \%$ (2015) and $20.3 \%$ (2016), whereas MD-I yield by $29.0 \%(2015)$ and $40.2 \%(2016)$. MD-II yield per shoot was $22.5 \%$ (2015) and 39.6\% (2016) lower than $\mathrm{C}$ vines (Table 3 ). Number of clusters per vine did not differ among treatments in both years (2015: $P=0.317$; 2016: $P=0.167)$. In 2015 , the number of clusters per vine ranged from 34 (HD-I) to 36 (MD-II), whereas in 2016 from 33 (HD-I; MD-II) to 37 (C).

Defoliated vines had lower cluster weights compared with $\mathrm{C}$, which was the result of a lower number of berries per cluster rather than smaller berry size (Table 3 ). In 2015, vines defoliated early (HD-I and MD-I) had the lowest cluster weight and number of berries per cluster, whereas in 2016 vines defoliated mechanically, regardless of timing (MD-I and MD-II), had the lowest cluster weight and berries per cluster. There were few treatment effects on berry weight, except where MD-I berry weight was greater than that of MDII in 2015.

The final leaf area-to-yield ratio, calculated on a per-shoot basis, did not differ among treatments in 2015, whereas it was higher for MD-I as compared with HD-I in 2016 (Table 3 ). Leaf removal treatments did not impact bud fruitfulness in either year (Table 3). Bud fruitfulness, which was measured the spring following treatment application, varied from 1.94 (MD-II) to 2.06 (C) in 2016. In 2017, bud fruitfulness varied from 2.17 (C) to 2.48 (MD-II).

There were no differences in fruit composition (TSS, pH, TA) among treatments in either 2015 or 2016. Overall, TSS ranged from $19.5 \%$ (C) to $19.9 \%($ MD-I $)(P$ treatment $\times$ year $=$ 0.958 ), TA from $4.3 \mathrm{~g} \cdot \mathrm{L}^{-1}(\mathrm{MD}-\mathrm{I})$ to $4.5 \mathrm{~g} \cdot \mathrm{L}^{-1}(\mathrm{C})(P$ treatment $\times$ year $=$ 0.664 ), and $\mathrm{pH}$ from 3.74 (C) to 3.8 $($ HD-I) $(P$ treatment $\times$ year $=0.714)$.

In both years, the ELR vines (HD-I and MD-I) had shorter rachises than $\mathrm{C}$ vines, whereas MD-II did not influence the length of the rachis (Table 4). In 2015, HD-I and MD-I rachis length was $16.4 \%$ less than that of $C$ vines, whereas in 2016, 
HD-I and MD-I rachis length was $18.1 \%$ and $21.2 \%$ less than that of $\mathrm{C}$. MD-I reduced cluster compactness in both years, whereas HD-I and MD-II reduced compactness only in 2015 and 2016, respectively (Table 4). Retained dehiscent floral debris was lower in all defoliated treatments as compared with C (Table 4). In 2015, HD-I vines had a lower number of clusters infected by bunch rot as compared with $\mathrm{C}$ and MD-II vines. However, there was no significant treatment effect on severity of rot infection in either year and incidence of rot infection in 2016 (Table 4).

\section{Discussion}

One of our primary objectives was to determine if defoliation in the fruit-zone, applied either at prebloom or at fruit-set, could effectively reduce crop losses to bunch rot in a susceptible cultivar like Riesling. Defoliated vines had less dense canopies, a greater percentage of sun-exposed clusters, fewer berries per cluster, lower retention of floral debris, and, in some cases, less compact clusters-all intended effects associated with reduced bunch rot (Hed et al., 2009; Tardaguila et al., 2010; Wolf et al., 1997). However, none of the leaf removal treatments significantly reduced bunch rot severity, and bunch rot incidence was reduced only in 2015 by HD-I, when compared with C. Other studies in commercial vineyards have shown similar inconsistencies; however, in almost all cases, there was at least a numerical reduction in rot by ELR (B. Hed, unpublished data). The numerical reduction in losses to rot among the leaf removal treatments ranged from $\approx 1.2 \%$ to $2.0 \%$ to $2.8 \%$ for MDII, MDI, and HDI, respectively. Although these reductions would result in an economic benefit to the grower, yield reductions from leaf removal were much greater.

In previous studies, the bunch rot-reducing effects of ELR were mainly attributed to a lowering of cluster compactness induced by a lesser number of berries per cluster and, in

Table 1. Influence of defoliation treatments on removed and final leaf area per shoot of 'Riesling' grapevines. Data were averaged over the 2015 and 2016 seasons as the treatment by year interaction was not significant.

\begin{tabular}{|c|c|c|c|c|}
\hline \multirow[b]{2}{*}{ Treatment $^{z}$} & \multirow{2}{*}{$\frac{\text { Removed leaf area }\left(\mathrm{cm}^{2} / \text { shoot }\right)^{y}}{\text { Total }}$} & \multicolumn{3}{|c|}{ Final leaf area $\left(\mathrm{cm}^{2} /\right.$ shoot $)$} \\
\hline & & Main & Lateral & Total \\
\hline $\mathrm{C}$ & 0 & $2,095 \mathrm{a}^{\mathrm{x}}$ & 4,059 & 6,143 a \\
\hline HD-I & 549 a & $1,648 \mathrm{~b}$ & 3,301 & $4,879 \mathrm{~b}$ \\
\hline MD-I & $279 \mathrm{~b}$ & $1,731 \mathrm{~b}$ & 3,554 & $5,285 \mathrm{ab}$ \\
\hline MD-II & $\mathrm{NA}^{\mathrm{w}}$ & $1,754 \mathrm{~b}$ & 3,214 & $4,870 \mathrm{~b}$ \\
\hline$P$ value & $<0.001$ & 0.005 & 0.314 & 0.055 \\
\hline
\end{tabular}

${ }^{\mathrm{z}} \mathrm{C}=$ nondefoliated control; HD-I = hand defoliation of the first six basal leaves and laterals at stage E-L 18 (Coombe, 1995); MD-I = mechanical defoliation at stage E-L 18; MD-II = mechanical defoliation at stage E-L 27. ${ }^{\mathrm{y}} 1 \mathrm{~cm}^{2}=0.1550$ inch $^{2}$.

${ }^{\mathrm{x}}$ Means within columns followed by different letters are significantly different based on the Tukey-Kramer method $(P \leq 0.05)$.

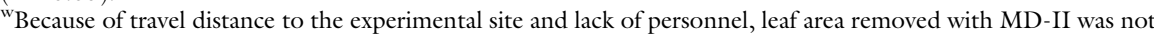
measured.

$\mathrm{NA}=$ not available some cases, smaller berry size (Hed et al., 2009, 2015; Palliotti et al., 2012; Tardaguila et al., 2010). In our study, defoliation did result in clusters with fewer berries, but did not consistently reduce cluster compactness, except in the case of MD-I. The inconsistency might be attributed in part to the effect of defoliation on cluster rachis length, which was reduced by ELR in both years when compared with C. Because we measured compactness as berries per centimeter, a shortening of the rachis would offset the loosening effect induced by fewer berries per cluster. This is a potential downside of ELR; and although the effect of ELR in reducing fruit-set is well documented, it is still unclear how defoliation at prebloom might influence rachis development (Acimovic et al., 2016). The one case in which ELR failed to reduce compactness was in 2016 with HD-I, when the reduction in rachis length $(\approx 18 \%)$ was slightly greater than the reduction in berries per cluster $(\approx 16 \%)$.

It is also important to recognize that the overall severity of bunch rot was low in both years of the study (severity rating was $<5 \%$ for all treatments). Canopy management practices implemented by the grower cooperator (shoot positioning, shoot thinning, and hedging) helped to maintain good fruit-zone spray coverage and microclimatic conditions that were unfavorable to the development of bunch rot and possibly other diseases, even in C. For example, little powdery mildew (Erysiphe necator) developed on 'Chardonnay' ( $V$. vinifera) vines with cluster exposure flux availability greater than $20 \%$ or cluster exposure layer values less than 1.5

Table 2. Impact of defoliation treatments on enhanced point quadrat analysis characteristics of 'Riesling' grapevines measured on 13 Aug. 2015 and 20 Aug. 2016. Data were averaged over the 2015 and 2016 seasons as the treatment by year interaction was not significant.

\begin{tabular}{lccccccc}
\hline Treatment & $\begin{array}{c}\text { Leaf } \\
\text { layers (no.) }\end{array}$ & $\begin{array}{c}\text { Interior } \\
\text { clusters (\%) }\end{array}$ & $\begin{array}{c}\text { Interior } \\
\text { leaves (\%) }\end{array}$ & $\begin{array}{c}\text { Occlusion } \\
\text { layers (no.) }\end{array}$ & $\begin{array}{c}\text { Cluster exposure } \\
\text { layers (no.) }^{\mathrm{x}}\end{array}$ & $\begin{array}{c}\text { Cluster exposure } \\
\text { flux availability (\%) }^{\mathrm{w}}\end{array}$ & $\begin{array}{c}\text { Leaf exposure } \\
\text { flux availability (\%) }\end{array}$ \\
\hline $\mathrm{C}$ & $2.22 \mathrm{a}^{\mathrm{v}}$ & $55.9 \mathrm{a}$ & $24.4 \mathrm{a}$ & $2.69 \mathrm{a}$ & $0.60 \mathrm{a}$ & $29.0 \mathrm{~b}$ & $42.9 \mathrm{~b}$ \\
$\mathrm{HD}-\mathrm{I}$ & $1.22 \mathrm{~b}$ & $16.5 \mathrm{~b}$ & $15.2 \mathrm{~b}$ & $1.79 \mathrm{~b}$ & $0.17 \mathrm{~b}$ & $63.6 \mathrm{a}$ & $57.6 \mathrm{a}$ \\
$\mathrm{MD}-\mathrm{I}$ & $1.31 \mathrm{~b}$ & $19.9 \mathrm{~b}$ & $15.5 \mathrm{~b}$ & $1.79 \mathrm{~b}$ & $0.21 \mathrm{~b}$ & $60.2 \mathrm{a}$ & $57.3 \mathrm{a}$ \\
$\mathrm{MD}-\mathrm{II}$ & $1.40 \mathrm{~b}$ & $20.4 \mathrm{~b}$ & $13.5 \mathrm{~b}$ & $1.87 \mathrm{~b}$ & $0.20 \mathrm{~b}$ & $57.3 \mathrm{a}$ & $55.0 \mathrm{a}$ \\
$P$ value & $<0.001$ & $<0.001$ & 0.0230 & $<0.001$ & $<0.001$ & $<0.001$ & 0.004 \\
\hline
\end{tabular}

${ }^{\mathrm{z}} \mathrm{C}=$ nondefoliated control; HD-I = hand defoliation of the first six basal leaves and laterals at stage E-L 18 (Coombe, 1995); MD-I = mechanical defoliation at stage E-L 18 ; $\mathrm{MD}-\mathrm{II}=$ mechanical defoliation at stage E-L 27.

yoclusion layer number is the number of shade-producing contacts (leaves and clusters) at one insertion point in the canopy (Meyers and Vanden Heuvel, 2008).

${ }^{\mathrm{x}}$ Number of shading layers between cluster and the boundary of the canopy (Mevers and Vanden Heuvel, 2008).

${ }^{\text {w }}$ Percentage, expressed as a decimal, of the above-canopy photo flux that reaches a cluster or leaf (Meyers and Vanden Heuvel, 2008).

${ }^{\mathrm{v}}$ Means within columns followed by different letters are significantly different based on the Tukey-Kramer method $(P \leq 0.05)$. 
Table 3. Impact of defoliation treatments on yield components and bud fruitfulness of 'Riesling' grapevines, vintage 2015 and 2016. Data were not combined over the years (2015-16) because of significant treatment by year interaction for some of the parameters.

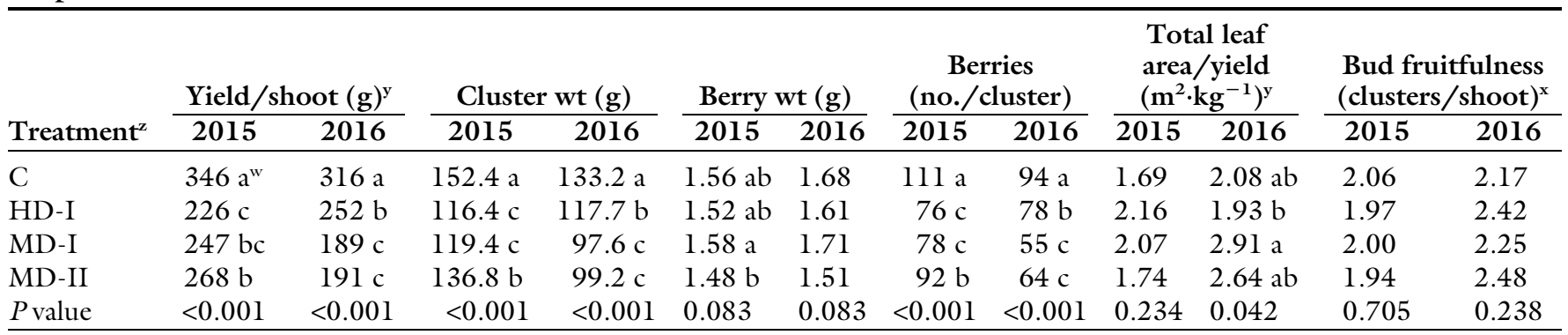

${ }^{\mathrm{z}} \mathrm{C}=$ nondefoliated control; HD-I = hand defoliation of the first six basal leaves and laterals at stage E-L 18 (Coombe, 1995); MD-I = mechanical defoliation at stage E-L 18; MD-II = mechanical defoliation at stage E-L 27.

${ }^{\mathrm{y}} \mathrm{l} \mathrm{g}=0.0353 \mathrm{oz}, \mathrm{l} \mathrm{m}^{2} \cdot \mathrm{kg}^{-1}=4.8824 \mathrm{ft}^{2} / \mathrm{lb}$.

${ }^{\mathrm{x}}$ Bud fruitfulness was collected in the spring following treatment applications (2016 and 2017).

${ }^{\mathrm{w}}$ Means within columns followed by different letters are significantly different based on the Tukey-Kramer method $(P \leq 0.05)$.

Table 4. Impact of defoliation treatments on bunch rot infections, number of debris, length of cluster's rachis, and cluster compactness of 'Riesling' grapevines, vintage 2015 and 2016. Data were not combined over the years (2015-16) because of significant treatment by year interaction for some of the parameters.

\begin{tabular}{|c|c|c|c|c|c|c|c|c|c|c|}
\hline \multirow[b]{2}{*}{ Treatment $^{\mathrm{z}}$} & \multicolumn{2}{|c|}{$\begin{array}{c}\text { Incidence of } \\
\text { bunch rot }(\%)^{y}\end{array}$} & \multicolumn{2}{|c|}{$\begin{array}{c}\text { Severity of } \\
\text { bunch rot }(\%)^{x}\end{array}$} & \multicolumn{2}{|c|}{ Debris (no./cluster) } & \multicolumn{2}{|c|}{$\begin{array}{l}\text { Length } \\
\text { rachis }(\mathrm{cm})^{\mathrm{w}}\end{array}$} & \multicolumn{2}{|c|}{ 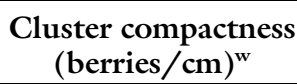 } \\
\hline & 2015 & 2016 & 2015 & 2016 & 2015 & 2016 & 2015 & 2016 & 2015 & 2016 \\
\hline $\mathrm{C}$ & $64.9 \mathrm{a}^{\mathrm{w}}$ & 50.4 & 4.92 & 4.58 & $33.0 \mathrm{a}$ & $13.3 \mathrm{a}$ & $7.9 \mathrm{a}$ & $6.6 \mathrm{a}$ & $10.7 \mathrm{a}$ & $10.9 \mathrm{a}$ \\
\hline HD-I & $47.7 \mathrm{~b}$ & 25.0 & 2.13 & 1.82 & $10.2 \mathrm{~b}$ & $6.0 \mathrm{~b}$ & $6.6 \mathrm{~b}$ & $5.4 \mathrm{~b}$ & $8.3 \mathrm{~b}$ & $11.0 \mathrm{a}$ \\
\hline MD-I & $59.4 \mathrm{ab}$ & 35.6 & 3.24 & 2.36 & $9.9 \mathrm{~b}$ & $2.3 \mathrm{~b}$ & $6.6 \mathrm{~b}$ & $5.2 \mathrm{~b}$ & $8.8 \mathrm{~b}$ & $9.2 \mathrm{~b}$ \\
\hline MD-II & $67.2 \mathrm{a}$ & 50.6 & 3.78 & 3.31 & $11.1 \mathrm{~b}$ & $6.0 \mathrm{~b}$ & $7.4 \mathrm{a}$ & $5.7 \mathrm{ab}$ & $9.7 \mathrm{ab}$ & $9.2 \mathrm{~b}$ \\
\hline
\end{tabular}

${ }^{\mathrm{z}} \mathrm{C}=$ nondefoliated control; HD-I = hand defoliation of the first six basal leaves and laterals at stage E-L 18 (Coombe, 1995); MD-I = mechanical defoliation at stage E-L 18 ; MD-II = mechanical defoliation at stage E-L 27.

yercentage of infected cluster.

${ }^{x}$ Percentage of infected berries per cluster.

${ }^{\mathrm{w}} 1 \mathrm{~cm}=0.3937$ inch, 1 berry $/ \mathrm{cm}=2.54$ berries/inch

${ }^{v}$ Means within columns followed by different letters are significantly different based on the Tukey-Kramer method $(P \leq 0.1)$.

(Austin et al., 2011). In our study, cluster exposure flux availability values were always greater than $20 \%$ and cluster exposure layer values were well less than 1.5 , even in $\mathrm{C}$ vines.

Our study confirmed that ELR is an effective tool for reducing crop yield, regardless of the method of application (Diago et al., 2010; Intrieri et al., 2008; Tardaguila et al., 2010). A reduction in crop level is desirable when it improves balance between reproductive and vegetative growth, fruit ripening, and wine chemistry in high-yielding wine grape cultivars (Arfelli et al., 1996; Bowen et al., 2011; Nuzzo and Matthews, 2006). However, yield reduction does not always translate into improved wine sensory perception or consumer willingness to pay more for the wine; thus, reducing crop level might result in loss of revenue for the wine grape grower (Preszler, 2012).

The effectiveness of mechanical defoliation in reducing yield, cluster weight, and number of berries per cluster was achieved with both prebloom and fruit-set application in both seasons, similar to previous work (Diago et al., 2010, 2012b). Regardless of the timing, reduction in yield was mainly explained by lower cluster weight and berries per cluster. This was fully expected for the prebloom treatments, but somewhat surprising for the fruit-set treatment. Self-regulating flower abscission was already occurring by this stage, but may have been incomplete when MDII was applied. Hence, other studies similarly reported that berry abortion after postbloom defoliation was a major factor affecting yield (Intrieri et al., 2008; Petrie et al., 2003, Poni et al., 2005).

The effect of defoliation on berry size was inconsistent. Defoliation at prebloom or fruit-set might decrease berry size due to carbohydrate limitation during the early stage of berry development (Poni et al., 2006, 2008; Tardaguila et al., 2010). However, berries of defoliated vines may grow more and reach full size because of the compensation effect from reduced number of berries per cluster (Hed et al., 2015; Lee and Skinkis, 2013; Poni and Bernizzoni, 2010).

Another goal of this study was to determine if MD-I could mimic the effects of HD-I, and therefore provide an alternative to hand leaf removal to overcome problems related to shortage of labor and timeliness of leaf removal. Despite MD-I having removed $\approx 50 \%$ less leaf area than HD-I, reductions in cluster compactness were more consistent with MD-I and effects on bunch rot severity, rachis length, floral debris retention, and EPQA characteristics were not different from HD-I. In addition, MD-I effects on crop reduction (yield/shoot) were similar (2015) or higher (2016) than HD-I. In 2016, the lower yield per shoot of MD-I compared with HD-I might be due to the machine blowing away some flowers (Diago et al., 2010). Although assessed in a subsequent year, 
we found that $\approx 38 \%$ of the inflorescences in MD-I had some type of damage, from a few missing flowers to small portions of the inflorescence missing. However, no inflorescences were heavily damaged or completely removed by the machine. In the present study, care was taken to ensure that shoots were within the catch wires to reduce the risk of damage to cluster or shoot tips by MD.

In our study, the lower yield of defoliated vines did not influence fruit maturity parameters (TSS, $\mathrm{pH}, \mathrm{TA}$ ). Although the total leaf area at harvest was lower in the HD-I and MD-II than in the $\mathrm{C}$, the final leaf area-toyield ratio, calculated on a per-shoot basis, was not below the range $(0.8$ $\left.1.2 \mathrm{~m}^{2} \cdot \mathrm{kg}^{-1}\right)$ for optimum fruit ripening (Kliewer and Dokoozlian, 2005). Several studies reported that although ELR did not affect fruit maturity, ELR vines had higher concentrations of phenolic compounds compared with nondefoliated vines (Lee and Skinkis, 2013; Tardaguila et al., 2010). Results were mainly explained by an improvement of fruit-zone microclimatic conditions favorable to the development of those compounds. In our study, canopy leaf density was lower and cluster sunlight exposure was higher in defoliated vines as compared with $\mathrm{C}$ vines 2 months after ELR was applied. Although not analyzed in this study, it might be possible that the greater sunlight exposure influenced the development of aroma compounds (e.g., C13-norisoprenoid) as previously reported for 'Riesling' growing in cool climate regions (Kwasniewski et al., 2010; Meyers et al., 2013).

\section{Conclusion}

In our study, leaf removal whether applied at prebloom or fruit-set was more effective at reducing yield parameters than improving bunch rot control when compared with $\mathrm{C}$ vines. Advancing the timing of MD from fruit-set to prebloom did not result in major changes in production parameters, canopy structure, fruit composition, and severity of bunch rot development. Despite removing only half the leaf area of HD-I, MD-I successfully mimicked HD-I in terms of improving cluster sunlight exposure, reducing cluster weight, berries per cluster, cluster compactness, and floral debris retention, in comparison with $\mathrm{C}$.
Therefore, MD-I may provide an alternative to HD-I, to reduce the effects of the increasing price and shortage of labor, and the timeliness of ELR.

\section{Literature cited}

Acimovic, D., L. Tozzini, A. Green, P. Sivilotti, and P. Sabbatini. 2016. Identification of a defoliation severity threshold for changing fruitset, bunch morphology and fruit composition in Pinot noir. Austral. J. Grape Wine Res. 22:399-408.

Alessandrini, M., F. Battista, A. Panighel, R. Flamini, and D. Tomasi. 2017. Effect of pre-bloom leaf removal on grape aroma composition and wine sensory profile of Semillon cultivar. J. Sci. Food Agr. 98:1674-1684.

Arfelli, G., R. Zironi, B. Marangoni, A. Amati, and M. Castellari. 1996. The effects of cluster thinning on some ripening parameters and wine quality. Acta Hort. 427:379-385.

Austin, C.G., G.G. Grove, J.M. Meyers, and W.F. Wilcox. 2011. Powdery mildew severity as a function of canopy density: Associated impacts on sunlight penetration and spray coverage. Amer. J. Enol. Viticult. 62:23-31.

Barbetti, M.J. 1980. Reductions in bunch rot in Rhine Riesling grapes from bunch thinning. Austral. Plant Pathol. 9:8-10.

Bowen, P., C. Bogdanoff, K. Usher, B. Estergaard, and M. Watson. 2011. Effects of irrigation and crop load on leaf gas exchange and fruit composition in red winegrapes grown on a loamy sand. Amer. J. Enol. Viticult. 62:9-22.

Caspari, H.W., A. Lang, and P. Alspach. 1998. Effects of girdling and leaf removal on fruit-set and vegetative growth in grape. Amer. J. Enol. Viticult. 49:359366.

Coombe, B.G. 1995. Adoption of a system for identifying grapevine growth stages. Austral. J. Grape Wine Res. 1:104-110.

Diago, M.P., B. Ayestarán, Z. Guadalupe, A. Garrido, and J. Tardaguila. 2012a. Phenolic composition of Tempranillo wines following early defoliation on the vines. J. Sci. Food Agr. 92:925-934.

Diago, M.P., B. Ayestaran, Z. Guadalupe, S. Poni, and J. Tardaguila. 2012b. Impact of prebloom and fruit-set basal leaf removal on the flavonol and anthocyanin composition of Tempranillo grapes. Amer. J. Enol. Viticult. 63:367-376.

Diago, M.P., M. Vilanova, and J. Tardaguila. 2010. Effects of timing of manual and mechanical early defoliation on the aroma of
Vitis vinifera L. Tempranillo wine. Amer. J. Enol. Viticult. 61:382-391.

English, J.T., C.S. Thomas, J.J. Marois, and W.D. Gubler. 1989. Microclimates of grapevine canopies associated with leaf removal and control of botrytis bunch rot. Phytopathology 79:395-401.

Hed, B., H.K. Ngugi, and J.W. Travis. 2009. Relationship between cluster compactness and bunch rot in Vignoles grapes. Plant Dis. 93:1195-1201.

Hed, B., H.K. Ngugi, and J.W. Travis. 2015. Short-and long-term effects of leaf removal and gibberellin on Chardonnay grapes in the Lake Erie region of Pennsylvania. Amer. J. Enol. Viticult. 66:2229.

Horsfall, J.G. and R.W. Barratt. 1945. An improved grading system for measuring plant disease. Phytopathology 35:655 (abstr.).

Intrieri, C., I. Filippetti, G. Allegro, M. Centinari, and S. Poni. 2008. Early defoliation (hand vs. mechanical) for improved crop control and grape composition in Sangiovese (Vitis vinifera L.). Austral. J. Grape Wine Res. 14:2532 .

Kliewer, W.M. and N.K. Dokoozlian. 2005. Leaf area/crop weight ratios of grapevines: Influence on fruit composition and wine quality. Amer. J. Enol. Viticult. 56:170-181.

Komm, B.L. and M.M. Moyer. 2015. Effect of early fruit-zone leaf removal on canopy development and fruit quality in Riesling and Sauvignon blanc. Amer. J. Enol. Viticult. 66:424-434.

Kwasniewski, M.T., J.E. Vanden Heuvel, B.S. Pan, and G.L. Sacks. 2010. Timing of cluster light environment manipulation during grape development affects $\mathrm{Cl} 3$ norisoprenoid and carotenoid concentrations in 'Riesling'. J. Agr. Food Chem. 58:6841-6849.

Lee, J. and P. Skinkis. 2013. Oregon Pinot noir grape anthocyanin enhancement by early leaf removal. Food Chem. 139:893-901.

Meyers, J.M., G.L. Sacks, and J.E. Vanden Heuvel. 2013. Glycosylated aroma compound responses in 'Riesling' wine grapes to cluster exposure and vine yield. Hort Technology 23:581-588.

Meyers, J.M. and J.E. Vanden Heuvel. 2008. Enhancing the precision and spatial acuity of point quadrat analyses via calibrated exposure mapping. Amer. J. Enol. Viticult. 59:425-431.

Nuzzo, V. and M.A. Matthews. 2006. Response of fruit growth and ripening to crop level in dry-farmed Cabernet 
Sauvignon on four rootstocks. Amer. J. Enol. Viticult. 57:314-324.

Palliotti, A., T. Gardi, J.G. Berrios, S. Civardi, and S. Poni. 2012. Early source limitation as a tool for yield control and wine quality improvement in a highyielding red Vitis vinifera L. cultivar. Scientia Hort. 145:10-16.

Petrie, P.R., M.C. Trought, G.S. Howell, and G.D. Buchan. 2003. The effect of leaf removal and canopy height on whole-vine gas exchange and fruit development of Vitis vinifera L. Sauvignon blanc. Funct. Plant Biol. 30:711-717.

Poni, S. and F. Bernizzoni. 2010. A threeyear survey on the impact of pre-flowering leaf removal on berry growth components and grape composition in $\mathrm{cv}$. Barbera vines. J. Intl. Sci. Vigne Vin 44:21-30.

Poni, S., F. Bernizzoni, G. Briola, and A. Cenni. 2005. Effects of early leaf removal on cluster morphology, shoot efficiency and grape quality in two Vitis vinifera cultivars. Acta Hort. 689:217-225.

Poni, S., F. Bernizzoni, and S. Civardi. 2008. The effect of early leaf removal on whole-canopy gas exchange and vine performance of Vitis vinifera L. Sangiovese. Vitis 47:1-6.

Poni, S., F. Bernizzoni, S. Civardi, and N. Libelli. 2009. Effects of pre-bloom leaf removal on growth of berry tissues and must composition in two red Vitis vinifera L. cultivars. Austral. J. Grape Wine Res. 15:185-193.

Poni, S., L. Casalini, F. Bernizzoni, S. Civardi, and C. Intrieri. 2006. Effects of early defoliation on shoot photosynthesis, yield components, and grape composition. Amer. J. Enol. Viticult. 57:397-407.

Preszler, T. 2012. Crop load adjustment in Vitis vinifera L. cv. Riesling. Cornell Univ., Ithaca, NY, PhD Diss.

Redman, G.E., E.P. King, and I.F. Brown. 1969. Elanco conversion tables for Barratt-Horsfall rating numbers. Elanco Products Co., Indianapolis, IN.

Reisch, B.I., R.M. Pool, D.V. Peterson, M. Howell-Martens, and T. HenickKling. 1993. Wine and juice grape varieties for cool climates. Cornell Coop. Ext. Info. Bul. 233.

Risco, D., D. Pérez, A. Yeves, J.R. Castel, and D.S. Intrigliolo. 2014. Early defoliation in a temperate warm and semi-arid Tempranillo vineyard: Vine performance and grape composition. Austral. J. Grape Wine Res. 20:111-122.

Sabbatini, P. and G.S. Howell. 2010. Effects of early defoliation on yield, fruit composition, and harvest season cluster rot complex of grapevines. HortScience 45:1804-1808.

Skinkis, P. 2013. Determining impact of hand or machine leaf removal on fruit quality. 10 Dec. 2013. <http://blogs. oregonstate.edu/owri/2013/12/10/ determining-impact-ofmachine-leafremoval-on-fruit-quality $/>$.

Steel, C.C., J.W. Blackman, and L.M. Schmidtke. 2013. Grapevine bunch rots: Impacts on wine composition, quality, and potential procedures for the removal of wine faults. J. Agr. Food Chem. 61:5189-5206.

Tardaguila, J., F. Martinez de Toda, S. Poni, and M.P. Diago. 2010. Impact of early leaf removal on yield and fruit and wine composition of Vitis vinifera L. Graciano and Carignan. Amer. J. Enol. Viticult. 61:372-381.

U.S. Department of Agriculture. 2017. Web site for official soil series descriptions and series classification. 19 Apr. 2018. <https://soilseries.sc.egov.usda.gov>.

Vail, M.E. and J.J. Marois. 1991. Grape cluster architecture and the susceptibility of berries to Botrytis cinerea. Phytopathology 81:188-191.

Vail, M.E., J.A. Wolpert, W.D. Gubler, and M.R. Rademacher. 1998. Effect of cluster tightness on botrytis bunch rot in six Chardonnay clones. Plant Dis. 82: 107-109.

Wolf, T.K. 2008. Wine grape production guide for eastern North America. Natural Resources Agr. Eng. Serv., Ithaca, NY.

Wolf, T.K., A.B.A.M. Baudoin, and N. Maritinez-Ochoa. 1997. Effect of floral debris removal from fruit clusters on botrytis bunch rot of Chardonnay grapes. Vitis 36:27-33.

Zitter, S.M. and W.F. Wilcox. 2004. Ontogenic, physical, and cultural factors affecting the initiation and spread of botrytis bunch rot of grapes, p. 64. In: N. Delen and Y. Elad (eds.). Proc. XIII Intl. Botrytis Symp. (abstr.). 